\title{
Study on Symbiotic Mechanism of the Industrial Clusters Ecosystem Based on City Innovation
}

\author{
Yu Xizhan ${ }^{1}$, Sui Yinghui $^{2}$ \\ ${ }^{1}$ Shandong University of Science and Technology, Taian 271000, China \\ ${ }^{2}$ Economic Research Institute of the Academy of Social Sciences of Qingdao, Qingdao 266071, China
}

\begin{abstract}
In industrial ecosystem, the symbiotic relationship and mechanism of the various communities are the keys to normal operating such as natural ecosystems. In the process of industry innovation, the Community main bodies, such as enterprises, universities and research institutions, intermediary institutions and governments, play different roles. Under the symbiotic environment formed by city innovation system, the cooperation innovation in community main bodies is carried out to achieve the system functions.

Index Terms - city innovation, industrial cluster, ecosystem, symbiotic mechanism
\end{abstract}

"Symbiosis" was proposed by Anton De Bary German biologist in 1879 - Symbiosis not only exists in the biosphere, also spreads out social systems. Over the last decade, symbiosis theory gradually extended to the field of economics and sociology. Thus the lessons could be drawn from the theory to study the industrial clusters ecosystem on city innovation.

\section{Connotation and composition of the industrial clusters ecosystem on city innovation}

Due to the variability and complexity of modern social, to advance the development of industrial clusters relies on the multilateral cooperation, such as enterprises, universities, research institutions, government and intermediaries. In the process of industrial innovation, they collaborate with their own advantages, and jointly advance scientific and technological innovating. Thus the industrial clusters ecosystem on city innovation is composed by these principal innovation bodies and their interaction relationships. By symbiosis theory, the symbiosis system is constituted by units, mode and environment. In three factors, the unit is a foundation, the environment is conditions and mode is the key factor.

\section{A. The Definition of Symbiosis Unit}

In Fig.1, as a result of the principal innovation bodies differently acting on and participating in the Industrial innovation, a hierarchy of symbiotic interfaces can be built in the industrial clusters ecosystem on city innovation, and different symbiotic units are formed, which comprise four kind of symbiotic units: enterprises, universities and research institutions, government and intermediary services (technology, social capital, etc.) . They are the fundamental units for symbiont to exchange matter and energy. And their characteristics can be described by a series of basic quality parameters, which reflect the internal properties of the symbiosis unit.
1) Enterprises is the most important symbiotic unit, the main body of investment and innovation activities, and also the most direct actor in the innovation added value. The enterprise-center symbiont is the key point and origin to study symbiotic system of industrial cluster. Its function mainly influences on forming the boundary of symbiotic system, allocating resource, improving of the symbiosis network, encouraging information and knowledge to flow, and so on.

2) Universities and research institutions are the main symbiotic units and the important sources of scientific research and innovation. As the primary creators and providers of knowledge and technology, universities and scientific research institutions not only directly involved in activities such as knowledge creating, disseminating and applying, but also participate in technological innovation activities by establishing businesses or enterprises and cooperating with other units.

3)Intermediary agencies, the main symbiotic units, are not directly involved in the creative process, and only plays a good role in assisting, communicating, coordinating and facilitating among government and universities, enterprises, society and market. And they also can provide financial support for other units.

4) Government also don't directly participate in innovation activities. But it plays an important role in promoting the function implementation of symbiotic system. It actively facilitate formation and development of the symbiosis network by building the industrial cluster symbiosis environment, and affects the entire innovation process by way of encouragement, guidance, coordination and protection .

\section{B. Symbiotic Mode Selection}

In the industrial cluster ecosystem, symbiosis model is the important way among symbiotic units to exchange information, energy and material, and is the decisive factor to influence the depth, breadth and cooperative forms among the main innovation bodies. Only benefiting from the system for their conducive developing, could the interdependence and cooperative relations be established among symbiotic units with their common goals, and be maintained sustainably and stably for a long time. To commonly developing and evolving, the symbiotic units select the corresponding symbiotic mode with the symbiotic goals and their own development needs, which includes of point symbiosis model, intermittent symbiosis model, continuous symbiosis model and integrated symbiosis model (As TABLE 1). 


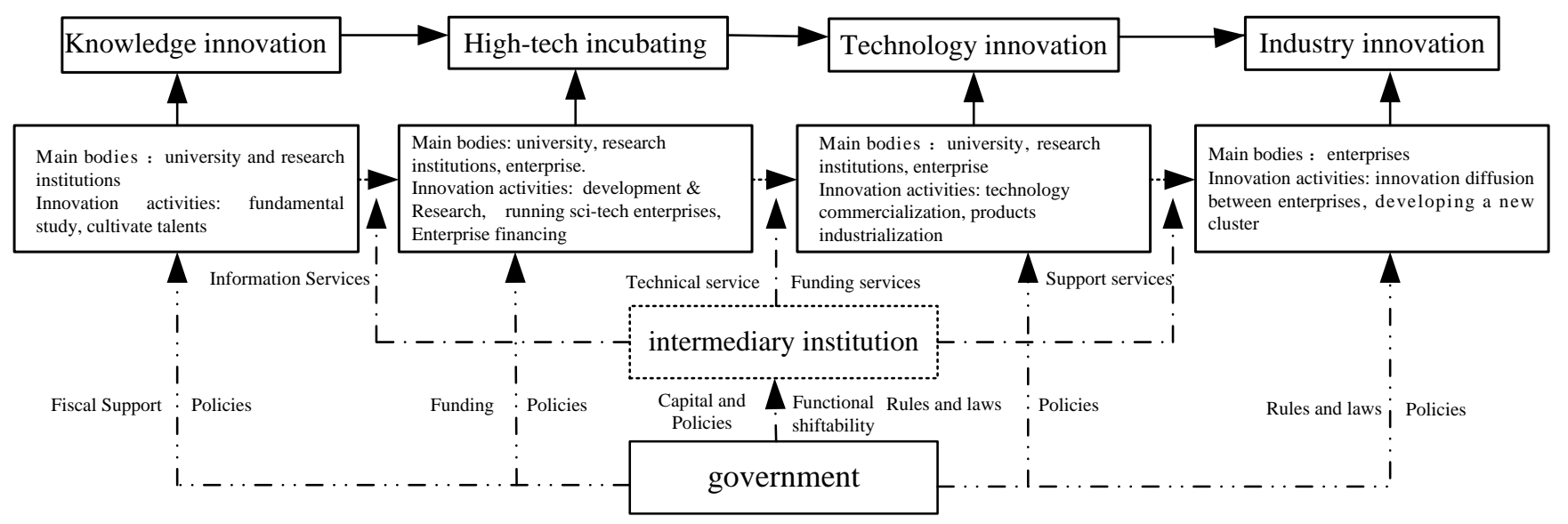

Fig.1 The industrial innovation process and its main participants

TABLE 1 The Classification of Cluster Ecosystem Symbiotic Model on Mineral Resources CityInnovation

\begin{tabular}{|l|l|l|l|}
\hline \multicolumn{1}{|c|}{ Patterns } & \multicolumn{1}{|c|}{ Implications } & \multicolumn{1}{c|}{ Symbiotic characteristics } & \multicolumn{1}{c|}{ Application mode } \\
\hline Point symbiosis & $\begin{array}{l}\text { interacting once among symbiotic cells at a } \\
\text { particular time }\end{array}$ & $\begin{array}{l}\text { Opening strongly, strong random, poor } \\
\text { stability, no symbiotic evolution }\end{array}$ & Technology transfer programs \\
\hline Intermittent symbiosis & $\begin{array}{l}\text { Under the condition of uncertainty and random, } \\
\text { interacting multiple times among symbiotic cells }\end{array}$ & $\begin{array}{l}\text { Strong open, poor stability, obviously } \\
\text { evolving }\end{array}$ & $\begin{array}{l}\text { Commissioned research programs } \\
\text { joint research programs }\end{array}$ \\
\hline Continuous symbiosis & $\begin{array}{l}\text { Under more stable and inevitable condition, } \\
\text { interacting multiple times continuously in several } \\
\text { ways among symbiotic cells }\end{array}$ & $\begin{array}{l}\text { Poorer openness, strong stability and } \\
\text { specificity, more strongly evolving }\end{array}$ & $\begin{array}{l}\text { Build scientific research bases } \\
\text { through joint efforts }\end{array}$ \\
\hline Integrated symbiosis & $\begin{array}{l}\text { Under stable and inevitable condition, symbiont } \\
\text { with independent nature and function being } \\
\text { formulated among symbiotic cells }\end{array}$ & $\begin{array}{l}\text { poor openness, strongest stability and } \\
\text { specificity, most strongly evolving }\end{array}$ & $\begin{array}{l}\text { Set up research and development } \\
\text { entities and industrial technology } \\
\text { alliance }\end{array}$ \\
\hline
\end{tabular}

\section{Symbiosis Environment}

The ideal symbiotic environment is positive for improving the industry cluster symbiosis ecosystem. Symbiotic environment can be defined from the macrocosm and microcosm, which determines the speed and efficiency of transmitting material and energy among the symbiotic units. The symbiotic environment makes an important influence on the emergence and development of the symbiotic relationship among symbiotic cells, which involves with policy, spatial geographical, network and social environments. Respectively, they could be separately measured with related indexes (As TABLE 2), such as policy support, the degree of spatial aggregation, complete information, and so on.

TABLE 2 The Classification and Measure System of Symbiotic Environment

\begin{tabular}{|c|c|c|c|}
\hline Classification & Measuring index & Classification & Measuring index \\
\hline \multirow{6}{*}{ Policy support } & Innovation policy & \multirow{4}{*}{ The completeness of information } & Symbiotic subject behavior \\
\hline & Technology transfer policy & & Technical characteristic \\
\hline & Incentive system & & Technology maturity \\
\hline & Tax credit & & Market maturity \\
\hline & Financial subsidies & \multirow{2}{*}{ Clustering level } & Number of research institutions \\
\hline & Financial support & & Number of enterprises \\
\hline \multirow{3}{*}{ The degree of networking } & Venture capital investment & \multirow{3}{*}{ Sincerity degree } & Trust valuation on government \\
\hline & Intermediary institutions & & Trust valuation on intermediaries \\
\hline & Information platform (database) & & Trust valuation on symbionts \\
\hline
\end{tabular}




\section{Analysis on symbiosis mechanism}

\section{A. Symbiosis Mechanism}

In the industrial cluster ecosystem, the key to effectively establish a symbiotic relationship and sustained over a long period of time is whether a certain symbiosis interface is built up among symbiotic units. The symbiosis interface is not only the foundation of symbiotic mechanism, but also the prime prerequisite for symbiotic system surviving and developing.
The symbiosis interfaces are the channels to transmit information, material and energy among enterprises, universities, research institutions, government and intermediaries. In different symbiosis environments, a variety of symbiotic interfaces can be produced among symbiotic cells (As TABLE 3). Generally, the more symbiotic interfaces and the greater contact surface are built, the better, the activities among symbiotic units and symbiotic effects are.

Tab. 3 The Analysis of Symbiosis Interface between Enterprises and Other Symbiotic Units in Cluster Ecosystem

\begin{tabular}{|c|c|c|c|c|}
\hline Symbiotic units & $\begin{array}{l}\text { Symbiotic } \\
\text { interface }\end{array}$ & Symbiotic mode & New symbiotic energy & Enterprise's new symbiotic energy \\
\hline \multirow{7}{*}{$\begin{array}{l}\text { University, } \\
\text { Research } \\
\text { institution }\end{array}$} & Professional & $\begin{array}{l}\text { Output high-quality talents, provide on- } \\
\text { the-job training }\end{array}$ & Promote university Popularity & Talents who can make money \\
\hline & \multirow{5}{*}{ Programs } & $\begin{array}{l}\text { Participate in planning and consultation } \\
\text { in many ways }\end{array}$ & Consulting fees, visibility & $\begin{array}{l}\text { To solve the enterprise management } \\
\text { problems }\end{array}$ \\
\hline & & cooperative project & $\begin{array}{l}\text { Research funds, the number of } \\
\text { published papers }\end{array}$ & $\begin{array}{l}\text { To solve important technical issues, to } \\
\text { increase production value }\end{array}$ \\
\hline & & $\begin{array}{l}\text { To build research \& development } \\
\text { centre }\end{array}$ & Research funds & $\begin{array}{l}\text { To achieve long-term development services, } \\
\text { access to new product new technology }\end{array}$ \\
\hline & & $\begin{array}{l}\text { University and local government } \\
\text { jointly manage science and technology } \\
\text { park }\end{array}$ & $R \& D$ funds & $\begin{array}{l}\text { Business profits, phased conversion results } \\
\text { for the mass production, training innovative } \\
\text { talents }\end{array}$ \\
\hline & & Running enterprises & $\begin{array}{l}\text { R \& D funds ,transforming } \\
\text { Scientific Results }\end{array}$ & Business profits \\
\hline & Market & $\begin{array}{l}\text { Transfer of achievement in science and } \\
\text { technology With technology market }\end{array}$ & Technology transfer fee & $\begin{array}{l}\text { Highly technical maturity, technological } \\
\text { achievements bringing commercial profit } \\
\text { potential }\end{array}$ \\
\hline \multirow{3}{*}{ Intermediaries } & Information & $\begin{array}{l}\text { Technology and innovation } \\
\text { information communication }\end{array}$ & Agency fees & $\begin{array}{l}\text { Industry, government and technology } \\
\text { information }\end{array}$ \\
\hline & Technology & $\begin{array}{l}\text { Integrate technology innovation } \\
\text { resources and Promote application of } \\
\text { technology }\end{array}$ & Technical service fee & Solve technical problem \\
\hline & Training & $\begin{array}{l}\text { Providing skills and management } \\
\text { training }\end{array}$ & Technical training fee & Enhance staff skills and management ability \\
\hline \multirow{4}{*}{ Government } & \multirow{3}{*}{ Fiscal policy } & $\begin{array}{l}\text { Establish and perfect market system, } \\
\text { build a competitive market } \\
\text { environment }\end{array}$ & $\begin{array}{l}\text { Tax, GDP, Regional rapid } \\
\text { development, industrial } \\
\text { competitiveness }\end{array}$ & $\begin{array}{l}\text { Market competition environment, expand } \\
\text { financing channels }\end{array}$ \\
\hline & & $\begin{array}{l}\text { Improve system policy for enterprise } \\
\text { technology innovation }\end{array}$ & $\begin{array}{l}\text { Perfect system of systems and } \\
\text { policies }\end{array}$ & $\begin{array}{l}\text { Technical standards, risk management } \\
\text { system, intellectual property system, etc., } \\
\text { good social and cultural environment }\end{array}$ \\
\hline & & $\begin{array}{l}\text { To strengthen the construction of } \\
\text { technical market, optimize the } \\
\text { innovation pattern, improve the } \\
\text { efficiency of innovation. }\end{array}$ & $\begin{array}{l}\text { Tax, industrial } \\
\text { competitiveness }\end{array}$ & Technology channels \\
\hline & Cooperation & $\begin{array}{l}\text { Promote resource flow and enterprise } \\
\text { cooperation, increase the investment } \\
\text { dynamics, strengthen the international } \\
\text { technology cooperation }\end{array}$ & $\begin{array}{l}\text { Tax, industrial } \\
\text { competitiveness, Industrial } \\
\text { structure }\end{array}$ & Funds, human resources, technology \\
\hline
\end{tabular}

\section{B. The Reaction Mechanism of Symbiotic Relationship}

The symbiotic relationship can also be described by symbiosis-degree, and Symbiosis-coefficient.

\section{1) Symbiosis-degree}

If in the industrial cluster eco-system there are two symbiotic units: enterprise(E) and university (U), quality parameters $Z_{E} 、 Z_{U}$ are corresponded to them, thus the symbiosis-degree $\delta_{\mathrm{EU}}$ could be defined:

$$
\delta_{E U}=\frac{\mathrm{d} Z_{\mathrm{E}} / Z_{\mathrm{E}}}{\mathrm{d} Z_{\mathrm{U}} / Z_{\mathrm{U}}}=\frac{Z_{\mathrm{U}}}{Z_{\mathrm{E}}} \frac{\mathrm{d} Z_{\mathrm{E}}}{\mathrm{d} Z_{\mathrm{U}}} \quad\left(\mathrm{d} Z_{\mathrm{U}} \neq 0\right)
$$

$\delta_{\mathrm{EU}}$ reports the change scope of correlation and the degree of interaction energy between $Z_{E}$ and $Z_{U}$, which is the most directly reflects the symbiotic nature and law of development. As playing a major role in symbiotic relationship, the main quality parameters are only discussed. 
Assumes that $\mathrm{Z}_{\mathrm{E}}$ is the main quality parameter of the symbiosis unit $E$ and $Z_{U}$ is the main quality parameter of the symbiosis unit $\mathrm{E}$, then the characteristics of symbiotic degree can be defined as $\delta_{\mathrm{EU}}^{\mathrm{m}}=\delta_{\mathrm{EU}}$ :

$$
\delta_{\mathrm{EU}}^{\mathrm{m}}=\frac{Z_{\mathrm{mE}}}{Z_{\mathrm{mU}}} \frac{\mathrm{d} Z_{\mathrm{mE}}}{\mathrm{d} Z_{\mathrm{mU}}}
$$

$\delta_{\mathrm{EU}}^{\mathrm{m}}$ reflects the symbiosis characteristics of between $\mathrm{Z}_{\mathrm{E}}$ and $\mathrm{Z}_{\mathrm{U}}$ :

If $\delta_{\mathrm{EU}}^{\mathrm{m}}=\delta_{\mathrm{UE}}^{\mathrm{m}}>0$, they are the positive symmetric symbiotic relationship;

If $\delta_{\mathrm{EU}}^{\mathrm{m}} \neq \delta_{\mathrm{UE}}^{\mathrm{m}}>0$, they are non-symmetric positive symbiotic State;

If $\delta_{\mathrm{EU}}^{\mathrm{m}}=\delta_{\mathrm{UE}}^{\mathrm{m}}<0$, they are reverse symmetric symbiotic relationship

If $\delta_{\mathrm{EU}}^{\mathrm{m}} \neq \delta_{\mathrm{UE}}^{\mathrm{m}}<0$, they are asymmetric inverse symbiotic relationship.

Based on this analysis, a conclusion can be drawn that to improve innovation performance and promote innovation ability, a city must attract a variety of innovation subject and resources to build an ecological industry cluster innovation system to improve innovation performance and promote innovation ability. If to build a symbiotic relationship and then to achieve collaborative innovation and development, it is more important to Upgrade the Symbiosis degree among enterprises, universities, research institutions, media and government

\section{2) Symbiotic relationships}

If $\theta_{\mathrm{m}}$ represents the symbiotic relationship between enterprise(E) and university $(\mathrm{U})$, an equation can be given:

$$
\left\{\begin{array}{l}
\theta_{\mathrm{E}}^{\mathrm{m}}=\frac{\left|\delta_{\mathrm{EU}}^{\mathrm{m}}\right|}{\left|\delta_{\mathrm{EU}}^{\mathrm{m}}\right|+\left|\delta_{\mathrm{UE}}^{\mathrm{m}}\right|} \\
\theta_{\mathrm{U}}^{\mathrm{m}}=\frac{\left|\delta_{\mathrm{UE}}^{\mathrm{m}}\right|}{\left|\delta_{\mathrm{EU}}^{\mathrm{m}}\right|+\left|\delta_{\mathrm{UE}}^{\mathrm{m}}\right|}
\end{array}\right.
$$

Thus it can be seen that there is " $\theta_{\mathrm{E}}^{\mathrm{m}}+\theta_{\mathrm{U}}^{\mathrm{m}}=1$ ", and if $\theta_{\mathrm{m}}$ represents symmetric symbiotic relationship regardless of positive or negative symbiotic relationship, there always is " $\theta_{\mathrm{E}}^{\mathrm{m}}=\theta_{\mathrm{U}}^{\mathrm{m}}=0.5$ ". Thus the symbiotic relationship between $\mathrm{U}$ and $\mathrm{E}$ could be differentiated from the symbiotic coefficients.

If $\theta_{\mathrm{E}}^{\mathrm{m}}=0$, there is no any symbiotic relationship between them, for $\mathrm{E}$ don't have any effect on $\mathrm{U}$;

If $\theta_{\mathrm{E}}^{\mathrm{m}}=1$, there is a parasitic relationship between them, for $\mathrm{U}$ don't have any effect on $\mathrm{E}$, but $\mathrm{E}$ affects $\mathrm{U}$;

If $0<\theta_{\mathrm{E}}^{\mathrm{m}}<0.5$, there is a partial symbiotic relationship between them, for $\mathrm{U}$ have more effects on $\mathrm{E}$;

If $\theta_{\mathrm{E}}^{\mathrm{m}}=0.5$, there is a reciprocal relationship between them, for $U$ have equivalent effect on $E$;

If $0.5<\theta_{\mathrm{E}}^{\mathrm{m}}<1$, there is a partial symbiotic relationship between them, for $E$ have more effects on $U$.

\section{Symbiotic Energy Regulation Mechanism}

Symbiotic energy is the key to maintain and develop symbiotic relationships. In the industrial clusters ecosystem based on city innovation, symbiotic energy is released from interaction with enterprises, universities, research institutions, intermediaries and government in cluster. The new energy being constantly produced, can strengthen incentive actions on symbiotic units. Further, a virtuous symbiotic circle is come into being to continuously promote the optimization and development of the system. On the contrary, no enough symbiotic energy would gradually degenerate, even dying. Whether symbiosis energy could be generated depends on the total factor symbiotic degree $\left(\delta_{\mathrm{s}}\right)$ in the system.

If there are $m(m \geq 2)$ nodes (symbiotic units) in industrial cluster eco-system, and $\mathrm{Z}_{\mathrm{i}}$ respectively represents the qualitative parameter of each node, the relation between $Z_{s}$ 与 $\mathrm{Z}_{\mathrm{i}}$ can be indicated that " $\mathrm{Z}_{\mathrm{s}}=\mathrm{f}\left(\mathrm{Z}_{1}, \mathrm{Z}_{2}, \ldots, \mathrm{Z}_{\mathrm{i}}, \ldots, \mathrm{Z}_{\mathrm{m}}\right)$ ". If there are the total factor symbiotic degree $\left(\delta_{\mathrm{s}}\right)$ and the symbiotic damping coefficient $(\lambda)$, then the relation between them can be indicated :

$$
\delta_{\mathrm{s}}=\frac{1}{\lambda} \sum_{\mathrm{i}=1}^{\mathrm{m}} \zeta_{\mathrm{i}} \quad(0<\lambda)
$$

For the innovation symbionts in the industrial clusters ecosystem based on city innovation, there is a clear correspondence between symbiotic energy $\left(\mathrm{E}_{\mathrm{s}}\right)$ and the total factor symbiotic degree $\left(\delta_{\mathrm{s}}\right)$, of the symbiosis density $\left(\rho_{\mathrm{s}}\right)$ and symbiotic dimension $\left(\eta_{\mathrm{s}}\right)$. It can be indicated that:

$$
E_{\mathrm{s}}=\mathrm{f}\left(\delta_{\mathrm{s}}, \rho_{\mathrm{s}}, \eta_{\mathrm{s}}\right)
$$

Therefore, in order to add value to system efficiency or benefit the value-added system or expand the scale of development systems, some appropriate measures on those subjects must be taken with the industrial clusters ecosystem.

1) Enhance the interaction efficiency of symbiotic interface. By enhancing their own qualities of symbiotic units and all elements, improving symbiotic interface functions and bettering symbiotic relationships, transaction costs would be reduced and the resistance between the symbiotic interfaces would also be diminished.

2) Advance the symbiosis symbiotic degree between the units. The $\delta_{\mathrm{s}}$ can elucidate the internal reactions among symbiotic units, and it plays a key role in generating energy and speeding up. The bigger $\delta_{\mathrm{s}}$ is, the greater symbiotic energy could be generated within the system.

3) Keep the symbiosis density $\left(\rho_{\mathrm{s}}\right)$ and symbiotic dimension $\left(\eta_{\mathrm{s}}\right)$ in a distance range. In symbiotic system, both symbiotic units size in a certain region (symbiosis density) should be controlled, and the number of the same category bodies in the same unit (symbiotic dimension) should be kept at a constant level. In the process of system developing, if each procedure of cooperative innovation processes wanted to achieve symbiotic effects maximization, the levels of symbiosis density and symbiotic dimension should be regulated gradually achieving equilibrium value and maintaining this level state. 


\section{Conclusions}

In particular symbiotic environment of city innovation, the symbiotic relationships and symbiosis mechanism were formulated from interactions and interdependence among symbiotic cells. Further, these symbiotic units cooperate with industry innovation as the core content to achieve overall function of entire system by virtue of the symbiosis mechanism and mode.

\section{References}

[1] A.E. Douglas. Symbiotic Interactions. Oxford: Oxford University Press, 1994: 3.

[2] Yu Xizhan, Sui Yinghui. The Industrial Clusters Ecosystem Based on City Innovation. Science \& Technology Progress and Policy, 2010(21): 56-60.

[3] Li Jianjun. Silicon Valley Model and Its University —industry Innovation System. Renmin University of China Doctoral Dissertation, 2000(6):5051.

[4] Si Shangqi, Cao Zhenquan, Feng Feng. Research on the Cooperation Mechanism of Institutions and Enterprises----A Symbiotic Theory and Analytical Framework. Science of Science and Management of S \& T, 2006(06): 15-19. 